\title{
Cultural Heritage and Social Environment Coherence in the Ethnographic Villages of Lithuania
}

\section{Vilma Karvelytė-Balbieriené*, Aušra Mlinkauskienè}

Kaunas University of Technology, Department of Architecture and Urbanism

Studentu St. 48, Kaunas 51367, Lithuania

${ }^{*}$ Corresponding author: vilma.karvelyte-balbieriene@ktu.lt

$\Gamma$

The records of the State protected cultural heritage objects in the preserved ethnographic villages of Lithuania; the survey records on their assessment; the guidelines on their potential use are considered to comprise a very significant part in the field of culturologic assessment. It is closely related to the needs and demands of the currently developed agricultural produce in these villages and the prevailing public services infrastructure as well as the social environment. When working out the issues related to the future heritage preservation and possibilities for the adaptation of these historic ethno cultureoriented rural settlements, the most decisive appeared the economic potential of the population in those villages. The state and conditions of the heritage objects in these ethnographic villages reflect not only the cultural attitude and provisions of the local communities, but the unregulated changes of the social economic environment.

The related project was carried out in 2012 called 'The assessment of the state and conditions of the prioritized ethnographic villages as well as the relics and objects of the immovable cultural heritage in those villages, by means of the analysis of the historical development and photo-fixation of the valuable objects and by the studies of the social environment of the local population' (Inventory... 2011). There was made an attempt to find out the current conditions of functioning of the prioritized preserved ethnographic villages, to determine the measures for protection as well as the prospects for future development. Based on the 'Inventory of the criteria for selecting the prioritized ethnographic villages' (Inventory... 2011) compiled from 38 villages which are included into the List of the Folk Art Valuables on Architecture, there were selected 10 prioritized villages. The assessment of the state and conditions of the immovable cultural heritage objects and social environment was performed in the following ethnographic villages of Salos, S. Katinautiskes, Kretuonos, Mikalajunai, Kasetos, Ziogeliai, Zervynos, Darguziai, Ciziunai ir Skirvytele. From the total number of 386 farmsteads, the detailed research study was performed in 188 farms. The findings of the study clarified the changes in the planned and spatial structure, the current state of the heritage objects of urbanism and architecture, the compositional characteristics in the landscape as well as the needs of the local communities and economic potentials for further protection of the ethno-architectural heritage.

KEYWORDS: ethnographic village, cultural heritage, value, social environment.

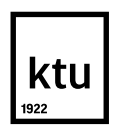

Journal of Sustainable Architecture and Civil Engineering Vol. 4 / No. 9 / 2014 pp. 5-15 DOI 10.5755/j01.sace.9.4.7546 (C) Kaunas University of Technology 
'Ethnographic village' is a rural settlement with the preserved traditional, historically survived, specific for that region, ethnic culture distinctiveness. The ethnographic villages signify themselves from the other villages by their original, extremely rich collection of ethnic culture-oriented values. They are ethno-architecture values (traditional structures and household items, planned and spatial structure, traditional way of location development, relation to the natural landscape), the monuments of archaeology, mythology, nature; the values and living traditions (life of the community, traditions of farming, businesses, trades, crafts, folk art, folklore, knowledge) (Project... 2003; wooden... 2010). The vitality of traditionally originated local communities of the ethnographic villages of Lithuania is a significant identity of the country's cultural traditions variety, an attribute of the national, regional, local diversity. The protection of these villages is based when taking into account only their ethno-architectural value, without taking into consideration their living culture and the unique traditions of their lifestyle and farming forced through the centuries. A clear emphasis on the architectural value of these villages does not fully reveal their ethno-cultural identity, prevents the comprehensive assessment of their cultural, economic and educational and recreational attraction. 'Ethnographic villages differ from the remaining villages of Lithuania by their economic, social and cultural living conditions and potentials for development, but the future vision of these villages require to apply an original concept in terms of their development (Project... 2003). In the validated legal documents of Lithuania there are prescribed the measures for the ethnic culture heritage preservation and for support of the phenomena of the living ethnic culture. However, they are insignificant and do not suspend the rapid disappearance of the wooden ethno-architectural heritage, together with the loss of the traditional communities. The decrease in the number of the working-age population in the villages causes the threat to the survival of the traditional architecture.

The Department of Architecture and Urbanism (KTU) initiated the research studies, regarding the architectural heritage of the selected prioritized ethnographic villages, in cooperation with the Division of the Protected Areas and Cultural Heritage (Ministry of Culture of the Republic of Lithuania). The derived results were applied for the implementation of the plan on The Ethnographic Villages Preservation for 2011-2013, approved in April 19, 2011 by the Ministry of Culture of the Republic of Lithuania and by the Ministry of Agriculture of the Republic of Lithuania (Inter-institutional... 2011). The objective of the plan is to provide legal and economic conditions for preservation of the ethnographic villages which were selected in accordance with the criteria of the assessment. The fundamental tasks of the plan are the following:

1 to accumulate, analyze and generalize the data on the state and conditions of the selected prioritized ethnographic villages;

7 to determine the work performance ranking concerning the required preparatory works for the selected prioritized ethnographic villages;

3 to promote the traditional life style and

3 traditional crafts in the ethnographic villages;

4 to contribute for promoting ethnographic

The objective of the article is to describe the qualitative and quantitative changes of the ethnocultural heritage in the investigated rural settlements of the ethnographic villages and to present the generalized reasons of their transformations. The significant task is to present the applied methods and means used during the performed research as well as to submit the derived results. The second stage has to involve the comparative analysis of the ethnographic villages of the neighboring countries made during the research expeditions. 


\section{Ethno-cultural heritage survey objectives, tasks, methodology for assessment}

According to the data of the Department of Cultural Heritage, there are 38 villages recorded on the list of the folk architecture valuables, 73 farmsteads and 193 individual structures. The project on 'The assessment of the state and conditions of the prioritized ethnographic villages as well as the relics and objects of the immovable cultural heritage in those villages, by means of the analysis of the historical development and photo-fixation of the valuable objects and by the studies of the social environment of the local population' (Inventory... 2011) 'determined the main objective of the research studies. After evaluating the characteristics of the social environment, it had to define the current conditions of the selected preserved ethnographic villages in terms of their functioning, define the possibilities of protection and the prospects of development. The tasks of the research, determined for the selected prioritized ethnographic villages, are the following:

_ to analyze the changes of the planned and spatial structure;

_ to carry out the analysis of the state of the urban and architectural heritage objects;

_ to evaluate the compositional peculiarities in the landscape;

_ to determine the main characteristics of the existing social environment and to describe its needs as well as the economic capacity.

During the research studies, the applied methodology for the assessment of the architectural heritage was based on the complex principle of the objects and their environment. The analysis was motivated by the cultural value research studies made by K. Šešelgis, dealing with the cultural heritage value analysis for urban and structural architecture and the methodology determining the systematic landscape cultural value (Lamauskas... 2003; Šešelgis... 1996).

The complex research studies were performed by integrating the analysis of the available publications, observations in situ, interview and survey of the local population, collecting and processing of the statistical and historical data, experimental evaluation. The main criteria of the assessment of the architectural heritage objects are authenticity, complexity, typicality, uniqueness, and historical informativeness. To define the cultural value and reasons for preservation of the urban and architectural heritage, the following requirements were taken into consideration:

1 the characteristics of the urban structure formation of the settlement, ranking the development of the territory i.e. time, change, scope;

the individuality of the pre-war development taking into account the characteristics of the planned $\angle$ structure, the compositional expressiveness of the spatial structure, type of development, harmony in the landscape;

3 the authenticity of the urban and architectural heritage objects and their physical state, assessing 3 the type of the post-war transformations, degree of physical depreciation, impact of the new constructional development.

The objective of the social environment survey is to determine the characteristic attributes of the social environment (demographic, institutional, statistical data etc.), in other words to describe the actual state and condition of the social environment by statistical methods. The survey in those settlements was directed towards the statistical recording of the current state and conditions of the local population (demographic composition of the families, education, profession, ability of farming etc.). The public opinion surveys by means of questionnaires made it possible to communicate directly with the respondents. The survey presented their own assessment of the residential ethno-cultural environment; the interests and needs of the owners of the ethnoarchitectural heritage were defined.

The research studies in the selected prioritized ethnographic villages were implemented by two stages: I. Archival collection of historical material and the analysis of it; II. Architectural and urban heritage studies and social environment survey conducted in the places of residence (the analysis 
of the valuable characteristics of the structures, physical state of the farmsteads and investigation of the changes of the valuable characteristics, sociological survey.

\section{The coverage of the cultural heritage analysis in the prioritized ethnographic villages}

The research was made in the villages according to the previously compiled list on the prioritized ethnographic villages of Lithuania. The research was performed in 10 prioritized ethnographic villages, which had been selected based on their physical state as well as the level of authenticity and in accordance with the request and tender?/proposals of the Ministry of Culture. The list of ten ethnographic villages according to the ethno-regions and the scope of the research work performed are presented in Table 1.

From the point of view of the territorial distribution, the most intensive studies were conducted in the ethnographic villages under the status of heritage protection, located in the south-eastern part of Lithuania. There are five villages in Dzukia, four villages in the eastern Aukstaitija. The

\section{Table 1}

List of the explored ethnographic villages by ethno-regions and scope of performed analysis

\begin{tabular}{|c|c|c|c|c|}
\hline No. & Settlement & $\begin{array}{l}\text { Preserved } \\
\text { area }\end{array}$ & $\begin{array}{c}\text { Type of } \\
\text { settlement }\end{array}$ & $\begin{array}{c}\text { Scope of performed } \\
\text { analysis }\end{array}$ \\
\hline 1. & $\begin{array}{l}\text { Salos } \| \text { (cultural } \\
\text { reserve, Ignalina } \\
\text { region) }\end{array}$ & $\begin{array}{l}\text { Aukstaitija } \\
\text { National Park } \\
\text {-ANP }\end{array}$ & $\begin{array}{l}\text { street -planned } \\
\text { village }\end{array}$ & $\begin{array}{r}\text { Explored in detail -100\% (four farms) } \\
\text { Interviewed } 4 \text { farmsteads }\end{array}$ \\
\hline 2. & $\begin{array}{l}\text { Senosios Katinautiskes } \\
\text { (Ignalina region) }\end{array}$ & - & 'rick' village & $\begin{array}{r}\text { Explored in detail -100\% } \\
\text { (10 farmsteads) } \\
\text { Interviewed } 9 \text { farmsteads }\end{array}$ \\
\hline 3. & $\begin{array}{c}\text { Kretuonos } \\
\text { (Svenconiai region) }\end{array}$ & ANP & $\begin{array}{l}\text { street -planned } \\
\text { village }\end{array}$ & $\begin{array}{r}\text { Explored in detail }-100 \% \\
\text { (22 farmsteads) } \\
\text { Interviewed } 10 \text { farmsteads }\end{array}$ \\
\hline 4. & $\begin{array}{c}\text { Mikalajunai } \\
\text { (Sirvintos region) }\end{array}$ & - & $\begin{array}{l}\text { street -planned } \\
\text { village }\end{array}$ & $\begin{array}{r}\text { Explored in detail }-100 \% \\
(24 \text { farmsteads) } \\
\text { Interviewed - } 10 \text { farmsteads }\end{array}$ \\
\hline 5. & Kasetos (Varena r.) & $\begin{array}{l}\text { Dzukija } \\
\text { National } \\
\text { Park- } \\
\text { DNP }\end{array}$ & $\begin{array}{l}\text { street -planned } \\
\text { village }\end{array}$ & $\begin{array}{r}\text { Explored in detail - 100\% } \\
\text { (16 farmsteads) } \\
\text { Interviewed - } 12 \text { farmsteads }\end{array}$ \\
\hline 6. & $\begin{array}{l}\text { Ziogeliai (etnocultural } \\
\text { reserve, Varena } \\
\text { region) }\end{array}$ & DNP & $\begin{array}{l}\text { scattered street } \\
\text {-planned village }\end{array}$ & $\begin{array}{r}\text { Explored in detail - 100\% } \\
\text { (16 farmsteads) } \\
\text { Interviewed - } 16 \text { farmsteads }\end{array}$ \\
\hline 7. & $\begin{array}{c}\text { Zervynos } \\
\text { (Varena region) }\end{array}$ & DNP & $\begin{array}{l}\text { street -planned } \\
\text { village } \\
\text { (protected by the } \\
\text { state) }\end{array}$ & $\begin{array}{r}\text { Explored in detail - 100\% } \\
\text { (42 farmsteads) } \\
\text { Interviewed - } 30 \text { farmsteads }\end{array}$ \\
\hline 8. & $\begin{array}{c}\text { Darguziai } \\
\text { (Varena region) }\end{array}$ & - & $\begin{array}{l}\text { street -planned } \\
\text { village }\end{array}$ & $\begin{array}{r}\text { Explored 100\% (a total of } 136 \\
\text { farmsteads) } \\
\text { In detail }-20 \text { farmsteads } \\
\text { Interviewed }-26 \text { farmsteads }\end{array}$ \\
\hline 9. & $\begin{array}{c}\text { Ciziunai } \\
\text { (Varena region) }\end{array}$ & - & $\begin{array}{l}\text { street -planned } \\
\text { village }\end{array}$ & $\begin{array}{r}\text { Explored 100\% (a total of } 100 \\
\text { farmsteads) } \\
\text { In detail } 18 \text { farmsteads } \\
\text { Interviewed } 9 \text { farmsteads }\end{array}$ \\
\hline 10. & $\begin{array}{l}\text { Skirvytele (ethno- } \\
\text { cultural reserve, Silute } \\
\text { region ) }\end{array}$ & $\begin{array}{l}\text { Nemuno } \\
\text { Delta } \\
\text { Regional Park }\end{array}$ & $\begin{array}{l}\text { street -planned } \\
\text { village }\end{array}$ & $\begin{array}{r}\text { Explored in detail - 100\% } \\
\text { (16 farmsteads) } \\
\text { Interviewed } 12 \text { farmsteads }\end{array}$ \\
\hline
\end{tabular}


mentioned above studies were also conducted in the region of Mazosios Lietuvos (Lithuania Minor) or Skirvyteles village. Totally, there were explored 188 farmsteads in a detailed way from the total number of 386 investigated ethnographic farmsteads (48\%), the sociological survey was conducted in 70 farmsteads (18\%). Six villages from ten bear the status of the protected areas where double legal protection regulation is prescribed, namely they are regulated not only by the Immovable Cultural Heritage Protection Acts of the Republic of Lithuania, but also by the Law on the Protected Areas of the Republic of Lithuania and by the subordinate legislation accompanying them.

In accordance with the cultural heritage status of the total number of ten investigated ethnographic villages, nine were registered under the Cultural Heritage Register, one village (Zervynos) was declared as protected by the State. However, there was determined that from ten investigated ethnographic villages; nine did not have any records except the registration of the separate structures under the legal status as the local significance architectural monument. The special plan was prepared only for Zervynos village in 2010 , where the cultural heritage requirements were prescribed and they indicated the system dealing with the particular measures of maintenance.

\section{The changes in the planned and spatial structure of the ethnographic villages}

The changes dated from the second half of the $20^{\text {th }}$ century in connection with planned and spatial structure registered in the explored ethnographic rural settlements (villages) turned to be rather diverse. The changes were pre-conditioned by the peculiarities of the geographic location and by the different indices of the social environment. In all the villages remained the network of the streets nearly unchanged together with the specific structure of development of the streets. However, since the second half of the $20^{\text {th }}$ century the perimeter of the streets development of villages have undergone partial transformations. During the survey the changes of the planned and spatial structure were observed in Katinautiskes, Mikalajunai, Kasetos, Zervynos and Ziogeliai; the village development dated since the beginning of the $19^{\text {th }}$ century remained unchanged until nowadays. However, at present there was observed a rapid decay of the aged farmsteads or even new functional transformations. There is a tendency in those villages to neglect or desolate farmsteads, where the former owned buildings are in a very poor state. In the streets of Darguziai, Ciziunai and Kretuonys developed in the Soviet period were halfway constructed new farmsteads, within the boundaries of the old farmsteads, or in new places when extending the perimeter of the street (Fig. 1).

The enumerated changes of the network of the streets and area development violate the integral ethno-architectural - urban texture. In future, the structural changes of these villages will not be so intense due to fast decrease of the number of the local population. The residential and subsistence farming function is disappearing together with the local population. The old farms in the village are gradually becoming holiday houses. Younger generation is acquiring and adapting them to the recreational purposes. Together with the increase of the recreational farmsteads, the mission of the aged buildings is changing; the structures used for farming purposes are adapted to the auxiliary facilities. The number of structures related to farming tends to be reduced but the

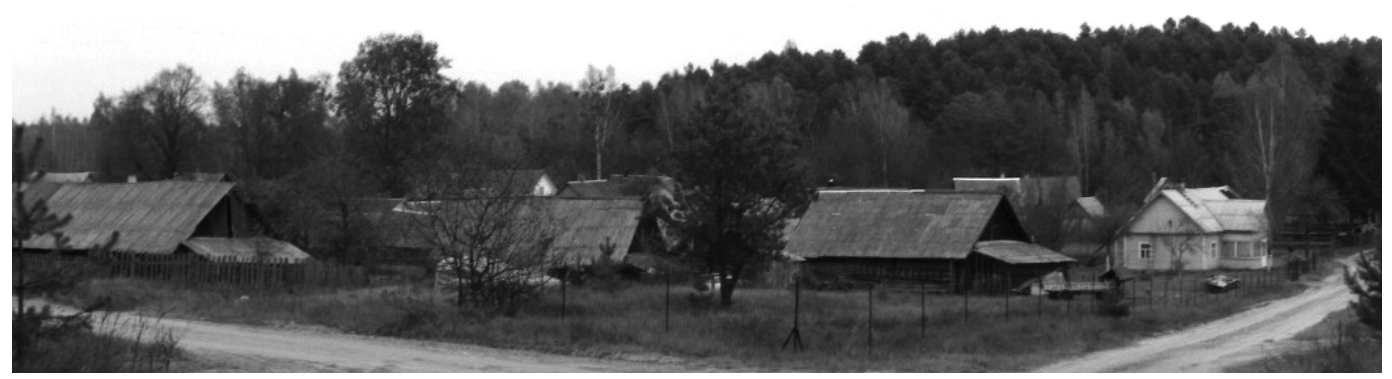

\section{Results of architectural heritage status survey in prioritized ethno- graphic villages}

Fig. 1

Panoramic view of ethnographic Ziogeliai village (The Principals... 2011) 
number of the accompanying buildings tends to be increased. In future, the whole village and the farmsteads will be gradually changed functionally into the recreational mission.

The example could serve Darguziai village, having three functional zones, the residential area, public area and productive or farming area. The residential area of the settlement according to the attributes of the plan is divided into three groups of farmsteads. The first group is the oldest part of the settlement (farmsteads 13-48), where the farmsteads are located close to each other and only on one side of the street, the plots by a narrow strip (17-40 $\mathrm{m}$ ) are adjacent to the street. The second group is comprised of the farmsteads 48-79; some of the farmsteads originated during the interwar period, the others settled as far as Grauzupis, were built much earlier, but were reconstructed after fire of 1944. The farmsteads occupy a large area and by a wider section (25-70 m) approach the street. The third group consists of the groups of the irregular form scattered farmsteads on both sides of the river, which were formed during the post-war years during the times of the collective farms establishment. All those groups of the farmsteads were settled and developed in accordance of the will of the farmstead owners, more or less affected by the architectural traditions of the village (Darguziai... 1966, 2003; Šešelgis... 1985; Report on Darguziai... 2011).

The village of Kretuonys developed evenly until 1900 is proved by the similar number of the constructed buildings. Before the First World War there were constructed 22 buildings, during the interwar period there were constructed 27 buildings, after the Second World War there were added 30 buildings ('Encyclopedia... 1998). After the restoration of Independence of Lithuania, the tendencies of the farmstead changes remained similar. Since 1989 there have been constructed 25 new buildings, which comprise $32 \%$ of the total number of the currently registered buildings (Report on Kretuonys... 2011). Since the second half of the $20^{\text {th }}$ century the number of the farmsteads in the village has been doubled, thus inevitably has influenced the structure of the farmsteads themselves as well as the general development of the village (Fig. 2).

\section{State and conditions analysis of the ethno-architectural heritage}

The mentioned above planned and spatial structural changes in the surveyed settlements indicate but not completely the diverse amount of the preserved architectural heritage and their physical

Fig. 2

Plan and local view of ethnographic Kretuonys village (Report on Kretuonys... 2011)
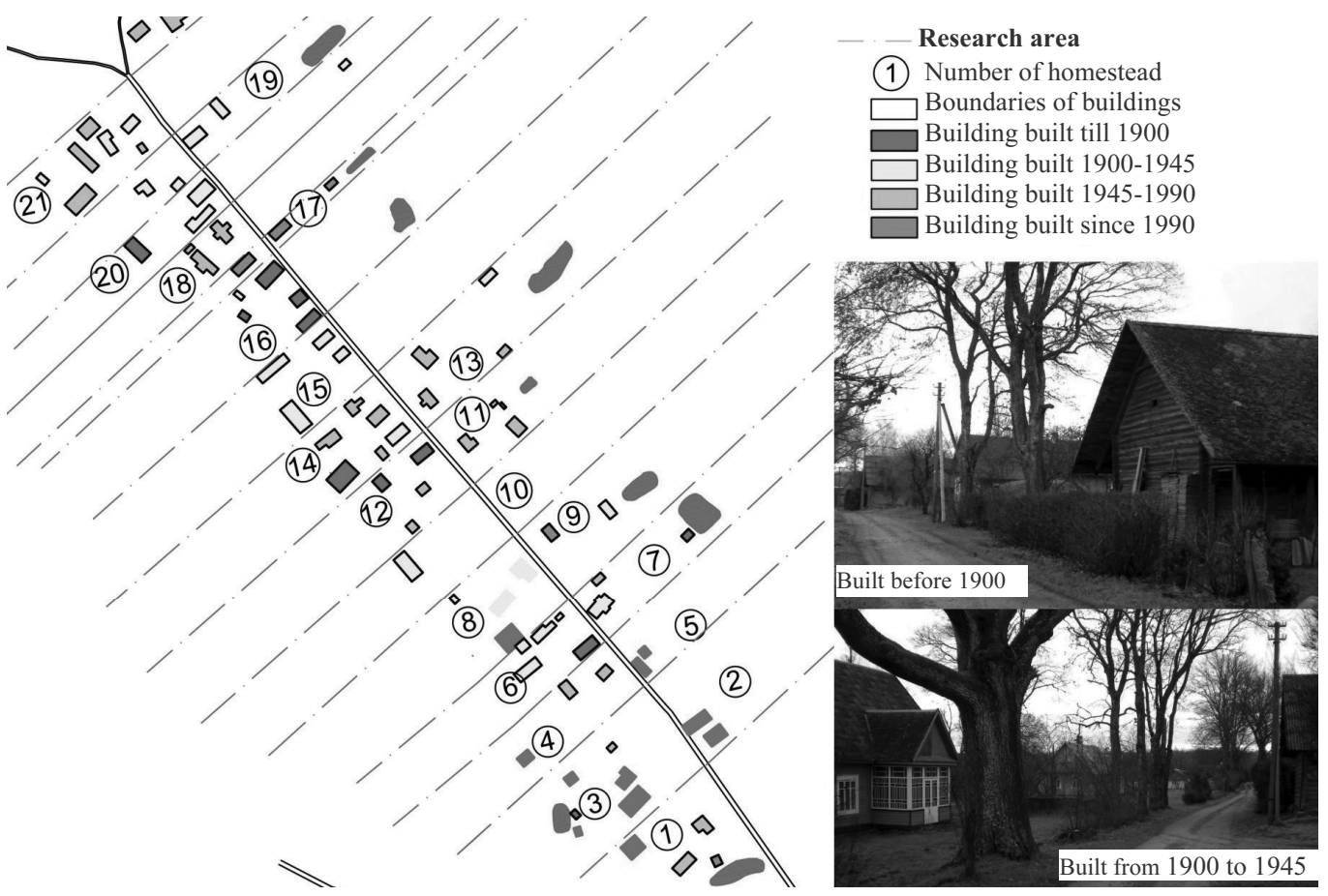
state. During the survey process it was proved, that the state and conditions of the architectural heritage in the ethnographic rural settlements, having different status of preservation, are different. The greatest impact had the geographical location in respect to the administrative centers, local recreational resources, social indices of the local community (age, household and economic potency etc.). After generalizing the data, collected during the research studies, there was revealed the fact that the largest part of the analyzed ethno-architectural heritage is of satisfactory or poor physical state. The performed analysis of the changes and physical state of the residential and farming purpose ethnographic structures assisted in defining that, from the specific objects of the traditional farmstead, are disappearing the structures of the
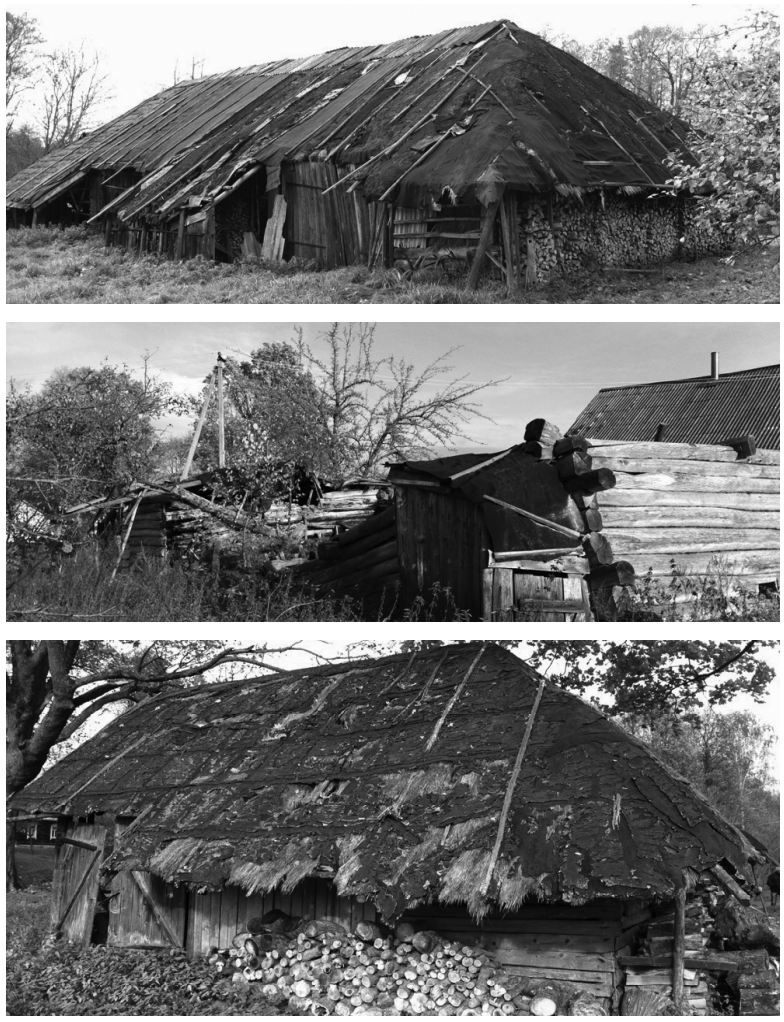
farming and auxiliary purpose especially fast such as sheds, clowns, barns and drying rooms for flax, stockyards (Fig. 3). Together with the disappearance of the subsistence farming, the structures of this group lose their initial assignment. In case, they are not adapted to the new function, they are becoming unused and abandoned. The barns could serve the example, which very similar to the residential buildings were used according to the initial purpose and therefore, they constituted better physical state.

\section{Compositional characteristics in the landscape of the ethnographic villages}

The growing interests of production and commerce have modified the priority of the traditional residential and sacral function in the landscape of the Lithuanian village since the middle of the $20^{\text {th }}$ century. The changes of the rural landscape nearly uncontrolled and little predictive have directly affected the social environment of the ethnographic villages as well as the cultural heritage. The specific compositional connection of these ethno-cultural heritage objects to the natural environment was formed even during the times of land reform or Wallach reform, from the middle of the $16^{\text {th }}$ century and was consistently developed until the middle of the $20^{\text {th }}$ century (Fig. 4).

\section{Results on the social environment state and conditions survey of the prioritized ethnographic villages}

After the assessment of the main characteristics, economic and cultural needs and demands of the set up structured social environment, there were defined the possibilities of use and protection of the preserved cultural heritage.

The sociological survey in the ethnographic villages was carried out in order:

to determine the attitude of local people towards the ethno-cultural values of the preserved landscape;

to define the opinion of the population on the prospects of maintenance of the ethnographic heritage in the rural residential territories.
Fig. 3

Physical condition of building's households in ethnographic village of Senosios Katinautiskes (Report on Senosios Katinautiskes... 2011) 


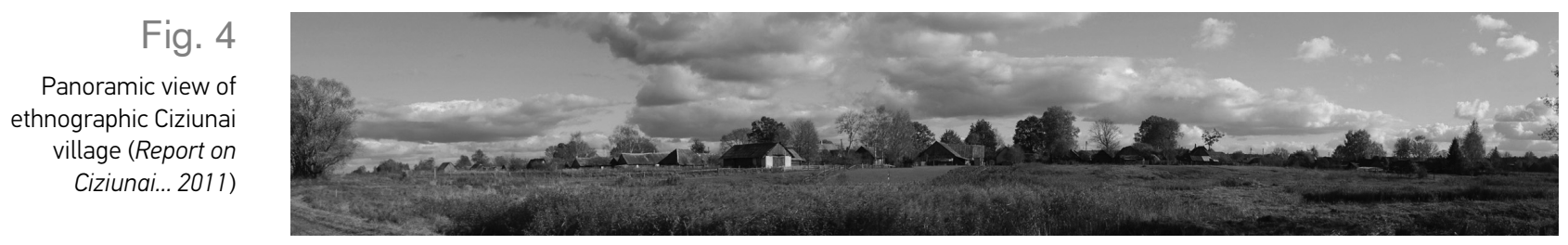

The summarized data of the survey disclosed the general opinion of the population of the rural residential settlements; however, the same indices in different rural settlements slightly differed.

The analysis of the survey data indicated that the majority of the respondents assessed negatively the heritage objects preservation considering it as too strict, which limited their farming activities and the construction of new buildings. Besides that, the population expressed the idea, that the information in respect to the allocated the administratively inspected status of the settlement was insufficient. The unsatisfactory information was in terms of the alternative activity potentials and education of the population itself, concerning the training and participation into the process for developing the environment in the preserved residential settlements.

It is possible to state, that the negative attitude of the local population towards the preservation and maintenance of the ethno-cultural heritage has been provoked by the following factors:

_ Limitations and restrictions of the constructional activities immobilizing local initiatives in farming or economic activities;

_ Limited understanding of the status of the settlement; lack of the regulatory interpretation and explanations in terms of activities; insufficient identification of the values; poor publicity of the procedures related to maintenance, use and assessment; inadequate promotion of the goals and significance of the valuable characteristics of the landscape preservation, because of the week communication and interaction of the administrative bodies with the local community.

The questionnaire of the sociological survey comprised 31 questions, the summary of which presented the essential issues, allowing to make the judgment on the currently dominating age of the population in the rural settlements, their financial potential in maintaining and preserving heritage objects, the attitude on the maintenance perspectives in future.

In the investigated rural settlements the dominating age is the retirement age, comprising even $51 \%$ of the total respondents, $22 \%$ of the respondents are in the age group of $41-50$ years, $16 \%$ of the respondents fit to 51-60 age group. In the other age groups such as up to 40 years, the number of the population is very insignificant or up to $10 \%$. A considerable part of the respondents (74\%) are the permanent residents of the surveyed ethnographic villages, $17 \%$ of the respondents visit the village very often - on weekends, and only $2 \%$ of the respondents come just on vacations. The ratio of the population in the settlements to the analyzed rural locations proved the following: the population who came from other villages amounted to $30 \%$, from towns came $33 \%$ of respondents and $32 \%$ of respondents were born there. The mentioned above three groups comprise a very similar percentage distribution. The percentage of population visiting as quests or temporary coming just for vacations is not great (5\%). The respondents informed that they were determined to continue living in that area and continue the maintenance and preservation of their residential environment according to accepted traditions.

During the survey there was made an attempt to clarify the possibility of heritage objects preservation and financing. Majority of respondents $64 \%$ indicated that both the State and the owner had to participate in the maintenance and preservation of the heritage objects; $14 \%$ of the respondents considered, that only by the State funds, they could reconstruct their farmsteads better; $17 \%$ indicated that they did not require anything additionally; they wanted their children to help in maintaining the household. A certain part of the population proposed the idea of private 
sponsors, but $5 \%$ of the respondents did not know who had to be involved into the maintenance and preservation of the heritage object. Even $35 \%$ of the respondents were able to contribute to the maintenance of the heritage buildings, $22 \%$ of respondents could contribute if their own buildings were maintained, $29 \%$ responded that they did not want to contribute to any similar kind of activity, $14 \%$ said they were not sure if they had been already determined. When the respondents were asked, what purpose they could use and how to adapt the old preserved buildings, half of the respondents answered, that those buildings could be used for tourist visits, however not a single expressed their wish to be engaged in that activity, the others considered that the structures could be used for cultural tourism, for representation or recreation.

The majority of the respondents were aware of the restrictions applied to their preserved farmsteads. In accordance with the current situation, the conclusion was derived, that validated restrictions interfered with the activities of the population in the territory, and it was necessary to return the residential function preference for the settlement in order to protect it from the disappearance.

1 The research studies made in the ethnographic villages and residential areas located around the church (further settlements) proved the planned and spatial structural changes of the settlements started in the second half of the $20^{\text {th }}$ century to be very diverse. It was destined due to the peculiarities of the geographic location and because of the different social environment indices. The network of the streets in all the analyzed settlements remained nearly unchanged; there survived the structure peculiar to the development of streets. However, since the second half of the $20^{\text {th }}$ century the traditional farmsteads in those villages and the general perimeter of the street development have undergone partial changes.

2 The mentioned above planned and spatial structure changes partly indicate the different quantity of the preserved architectural heritage as well as physical state in the investigated settlements. The greater part of the explored ethno-architectural heritage objects were in satisfactory or poor physical state. The analysis of the preserved ethnographic villages assisted in defining that for farming allocated structures and buildings, from the total number of the architectural heritage objects, tend to decay or disappear extremely fast, because of their diminished traditional farming activities that were rather difficult to adapt to a new function and were no longer in use.

3 The survey revealed the fact that in the ethnographic rural settlements having different 3 status of the valuable architectural heritage objects preservation survived unevenly. The greatest influence had the available local recreational resources, geographic location and social indices of the local community (age, farming and economic potential etc.).

The prioritized function of the traditional residential and sacral life in the Lithuanian rural 4 landscape was changed by the developing interests due to production and commerce dated back to the middle of the $20^{\text {th }}$ century. The changes of the rural landscape, partly unregulated and little predictive, has a direct impact on the transformations of the ethno cultural environment preconditioned by the character of the ethnographic villages. The mentioned above changes in the territories of the national and regional parks were almost invisible.

5 The needs and demands analysis related to social environment and the studies of the 5 physical and cultural changes of the preserved architectural heritage presented the fact, that the economic requirements of the population affected the cultural value of the buildings bearing the architectural value mostly negatively. After providing the survey of the local communities, it was determined, that the impact of the population both onto the architectural heritage objects and onto the valuable urban structure was chaotic. It was caused by the lack of the financial resources of the local population and insufficient specific knowledge, which determined the improper measures of preservation and maintenance of the ethno-architectural heritage objects to be able to adapt them to new functions. 


\section{References}

Darguziai. Minor Lithuanian Soviet Encyclopaedia (1966) T. 1 (A-J). Vilnius, Chief Editorial Board, 366 p. // Dargužiai. Mažoji lietuviškoji tarybinè enciklopedija, T. 1 (A-J). Vilnius, Vyriausioji enciklopedijų redakcija, 366.

Darguziai. Universal Lithuanian Encyclopaedia (2003), T. IV (Chakasija-Dirzių graveyards). Vilnius: Institute of Scientific Publication and Encyclopaedias, 502 p. // Dargužiai. Visuotinè lietuvių enciklopedija, T. IV (Chakasija-Diržių kapinynas). - Vilnius: Mokslo ir enciklopediju leidybos institutas, 502.

Encyclopedia on Cultural Heritage. Eastern Lithuania (1998), volume 1, II part., Vilnius // Kultūros paminklų enciklopedija. Rytų Lietuva, t. 1, Il d., Vilnius.

Inter-institutional plan of activities for 2011-2013 on the ethnographic village preservation, 2011. 04 19. No. [V-316/3D-348 [interactive]. [approved 2014 01 28]. Etnografinių kaimų išsaugojimo 2011-2013 metu tarpinstitucini veiklos planas, 2011 m. 0419 Nr. IV-316/3D-348 [interaktyvus]. [žiūrèta 201401 28]. Prieiga per internetą: https://www.e-tar.lt/ portal/rs/legalact/TAR.649271EFE57C/)/

Access from Internet: https://www.e-tar.lt/portal/ rs/legalact/TAR.649271EFE57C/)

Inventory of the criteria for selecting the prioritized ethnographic villages, 20111230 No. IV-818. [Interactive]. [revised in 201402 28]. Access from Internet: http://www.litlex.lt/scripts/sarasas2. dll?Tekstas $=1 \& \mid d=155780$ ) $\quad / / \quad$ Prioritetiniu etnografinių kaimu atrankos kriteriju aprašas, 20111230 Nr. IV-818. [interaktyvus]. [žiūrèta 2014 02 28]. Prieiga per internetą: http://www.litlex.lt/ scripts/sarasas2.dll?Tekstas $=1 \& l d=155780$ )

Lamauskas A., Bučas J., Dringelis L. (2003). Kultūrologiniai kraštovaizdžio ir architektūros paveldo tyrimai mokomoji knyga. KTU, Kaunas: Technologija, 129.

Project of the long-term program for preservation of Lithuanian ethnographic villages, www.llkc.lt, 2003. 09. 16. No. 1171. [interactive]. [approved 2014 03 02]. Access from Internet: http://www.llkc.lt/ index.php?2747543730 // Lietuvos etnografiniu kaimu išlikimo ilgalaikès programos projektas, 20030916 Nr. 1171. [interaktyvus].[žiūrèta 2014 03 02]. Prieiga per internetą: http://www.llkc.lt/ index.php?2747543730

Report of the Workshop on the Culturelogical Survey of Salu II village (2011). KTU, Department of Architecture and Urbanism./ PhD. Vilma
Karvelytė Balbierienė, PhD. Aušra Mlinkauskienè. Kaunas // Salų II kaimo kultūrologinių tyrimu praktikos ataskaita (2011). KTU, Architektūros ir kraštotvarkos katedra./ vad. dr. Vilma Karvelyte Balbierienè, dr. Aušra Mlinkauskienè. Kaunas.

Report of the Workshop on the Culturological Survey of Ciziunai village (2011). KTU, Department of Architecture and Urbanism / PhD. Vilma Karvelytė Balbierienè, PhD. Aušra Mlinkauskienè. Kaunas // Čižiūnų kaimo kultūrologinių tyrimų praktikos ataskaita (2011). KTU, Architektūros ir kraštotvarkos katedra./ vad. dr. Vilma Karvelyte Balbierienè, dr. Aušra Mlinkauskienė. Kaunas.

Report of the Workshop on the Culturological Survey of Darguziai village (2011). KTU, Department of Architecture and Urbanism / PhD. Vilma Karvelytė Balbierienè, PhD. Aušra Mlinkauskienè. Kaunas // Dargužių kaimo kultūrologinių tyrimų praktikos ataskaita (2011). KTU, Architektūros ir kraštotvarkos katedra./ vad. dr. Vilma Karvelyte Balbierienè, dr. Aušra Mlinkauskienè. Kaunas.

Report of the Workshop on the Culturological Survey of Kretuonys village (2011). KTU, Department of Architecture and Urbanism / kraštotvarkos / PhD. Vilma Karvelyte Balbierienè, PhD. Aušra Mlinkauskienè. Kaunas // Kretuoniu kaimo kultūrologiniu tyrimų praktikos ataskaita (2011). KTU, Architektūros ir kraštotvarkos katedra./ vad. dr. Vilma Karvelytė Balbierienè, dr. Aušra Mlinkauskienè. Kaunas.

Report of the Workshop on the Culturological Survey of Mikalajunai village (2011). KTU, Architecture and Urbanism/ PhD. Vilma Karvelytė Balbierienè, PhD. Aušra Mlinkauskienè. Kaunas // Mikalajūnu kaimo kultūrologiniu tyrimu praktikos ataskaita (2011). KTU, Architektūros ir kraštotvarkos katedra./ vad. dr. Vilma Karvelytè Balbierienè, dr. Aušra Mlinkauskienè. Kaunas.

Report of the Workshop on the Culturological Survey of Senosios Katinautiskes village (2011). KTU, Department of Architecture and Urbanism./ PhD. Vilma Karvelytė Balbierienè, PhD. Aušra Mlinkauskienè. Kaunas // Senosios Katinautiškès kaimo kultūrologinių tyrimų praktikos ataskaita (2011). KTU, Architektūros ir kraštotvarkos katedra./ vad. dr. Vilma Karvelytė Balbierienè, dr. Aušra Mlinkauskienè. Kaunas.

Report of the Workshop on the Culturological Survey of Skirvyteles village (2011). KTU, Department of Architecture and Urbanism./ PhD. Vilma Karvelytè Balbierienè, PhD. Aušra Mlinkauskienè. Kaunas // Skirvytèlès kaimo 
kultūrologinių tyrimų praktikos ataskaita (2011). KTU, Architektūros ir kraštotvarkos katedra./ vad. dr. Vilma Karvelytė Balbierienè, dr. Aušra Mlinkauskienè. Kaunas.

Report of the Workshop on the Culturological Survey of Ziogeliai village (2011). KTU, Department of Architecture and Urbanism./ PhD. Vilma Karvelytė Balbierienė, PhD. Aušra Mlinkauskienè. Kaunas // Žogelių kaimo kultūrologinių tyrimy praktikos ataskaita (2011). KTU, Architektūros ir kraštotvarkos katedra./ vad. dr. Vilma Karvelyte Balbierienè, dr. Aušra Mlinkauskienè. Kaunas.

Šešelgis K. Darguziai. Encyclopaedia of the Soviet Republic of Lithuania (1985). 1 (A-Grudas). Vilnius: Chief Editorial Board, 390 p. // Kazys Šešelgis. Dargužiai. Tarybų Lietuvos enciklopedija (1985), T. 1 (A-Grūdas). - Vilnius: Vyriausioji enciklopediju redakcija, $390 \mathrm{psl}$.

Šešelgis K.: Monuments of Folk Architecture of Lithuania (1996), volume, 4. South-eastern one- street villages of Lithuania, Vilnius // Kazys Šešelgis: Lietuvių liaudies architektūros paminklai (1996), t. 4. Pietryčių Lietuvos gatviniai kaimai, Vilnius.

The Principals of Maintenence of the Ethnographic Rural Settlements in the Preserved Territories. Survey on Kasetos, Ziogeliai and Zervynos Ethnographic Villages (2011) / Made by: Master Reda Driksaite / Head PhD. Vilma Karvelyte Balbierienè/ KTU, Department of Architecture and Urbanism, Kaunas // Etnografinių kaimo gyvenviečių saugomose teritorijose tvarkymo principai (2011). Kašetų, Žiogelių ir Zervynų etnografinių kaimu tyrimai./ Atliko: magistr. Reda Drikšaite / vad. dr. Vilma Karvelytè Balbierienè/ KTU, Architektūros ir kraštotvarkos katedra, Kaunas.

Wooden architecture heritage and policy of the national culture (2010). Resolution, International conference, Vilnius, 2 p. // Medinès architektūros paveldas ir nacionaline kultūros politika (2010). Rezoliucija, Tarptautinè konferencija, Vilnius, 2 p.

\section{VILMA KARVELYTE்-BALBIERIENE்}

\section{Lecturer}

Kaunas University of Technology, Faculty of Civil Engineering and Architecture, Departament of Architecture and Urbanism

\section{Main research area}

Protection of cultural heritage; research of small towns and ethnographic villages

\section{Address}

Studentu 48, LT-51367 Kaunas, Lithuania

Tel. +370 68236358

E-mail: vilma.karvelyte-balbieriene@ktu.lt

\section{AUŠRA MLINKAUSKIENĖ}

\section{Lecturer}

Kaunas University of Technology, Faculty of Civil Engineering and Architecture, Departament of Architecture and Urbanism

\section{Main research area}

Immovable cultural heritage; values of cultural landscapes, urban structures

\section{Address}

Studentu 48, LT-51367 Kaunas, Lithuania

Tel.+370 68479181

E-mail: ausra.mlinkauskiene@ktu.lt

\section{About the authors}

